\title{
Pembentukan, Karakterisasi Serta Manfaat Asam Humat Terhadap Adsorbsi Logam Berat (Review)
}

\author{
Firda1), Oviyanti Mulyani2), dan Anni Yuniarti2)
}

\begin{abstract}
1) Alumni Program Studi Agroteknologi Fakultas Pertanian Universitas Padjadjaran
2) Staff Pengajar Departemen Ilmu Tanah dan Sumberdaya Lahan Fakultas Pertanian Universitas Padjadjaran, Jl. Raya Bandung Sumedang Km 21 Jatinangor

Korespondensi: firdageorge@gmail.com
\end{abstract}

\begin{abstract}
Soil is a very complex and dynamic system, consisting of the solid, liquid and gas. The solid parts of soil is made from minerals and organic materials (rough and smooth). Organic materials with smooth from is called humic acid. This product is a result from oxidation polimeritation of compounds like phenol, lignin and proteins from plants also from the metabolism of microorganism in the ground. In general, the composition of organic matter is dominated by humin with large, medium and lower of molecular weight. Humic acid has the composition of elements like carbon (4080\%), nitrogen (2-4\%), sulfur (1-2\%), phospor (0-0,3\%) and also oxygen. Humic acid has unique characteristics compared with fulvic acid and humin. One of the most spesific character is the bonding to interact with metal ions, oxide, hydroxide, minerals, organic, and toxic materials.
\end{abstract}

Key words: Adsorbtion, Characterization, Heavy metals, Humic Acid

\section{PENGERTIAN DAN PEMBENTUKAN ASAM HUMAT}

Tanah adalah suatu sistem yang sangat kompleks dan bersifat dinamis, terdiri dari bagian padat, cair dan gas. Bagian padat dari tanah tersusun atas mineral dan bahan organik. Bahan organik tanah merupakan total komponen organik yang meliputi jaringan hewan dan tanaman yang tidak membusuk, hasil dekomposisi (residu organik), dan biomassa tanah (jaringan mikroba hidup) (Orlov, 1985). Bahan organik tanah yang sudah terdekomposisi sempurna dan secara mikroskopis tidak memiliki sel tumbuhan disebut humus. Bagian kecil dari humus terdiri dari gula dan asam amino yang larut dalam air, sedangkan bagian yang terbesar merupakan bahan yang tidak terlarut dalam air. Bagian ini disebut senyawa Humat yang merupakan hasil polimerisasi oksidasi dari senyawa-senyawa fenol, lignin, dan protein dari tanaman serta metabolisme dari biota tanah (Stevenson, 1994).

Senyawa humat tanah dapat digolongkan menjadi: a. Asam humat yang larut dalam basa

b. Asam fulfat yang larut dalam suasana asam maupun basa,

c. Humin yang tidak larut dan bersifat inert (Tan,1996).

Senyawa humat merupakan hasil biodegradasi lanjut dari lignin akibat tanah terpengaruhi oleh bakteri dalam tanah lembab ataupun yang berair. Proses degadrasi melibatkan proses:

- Demitilasi gugus $-\mathrm{OCH}_{3}$, menghasilkan gugus $\mathrm{OH}$ - fenolat

- Oksidasi gugus $-\mathrm{CH}_{2} \mathrm{OH}$ pada cincin terminal lignin membentuk $-\mathrm{COOH}$

- Pemecahan cincin aromatik lignin menghasilkan $-\mathrm{CH}_{2} \mathrm{OH}$, - $\mathrm{COH}$, maupun -COOH. Demitilasi dan oksidasi mengakibatkan tingginya kandungan gugus $-\mathrm{COOH}$ dan $\mathrm{OH}$ - fenolat. Proses biodegradasi lignin selalu disertai dengan pelepasan $\mathrm{CO}_{2}$. Pelepasan $\mathrm{CO}_{2}$ menyebabkan penurunan kadar oksigen dan karbon pada senyawa humat (Rahmawati, 2004). 
Asam humat merupakan bahan makromolekul polielektrolit yang memiliki gugus fungsional $-\mathrm{COOH},-\mathrm{OH}$ fenolat, maupun $-\mathrm{OH}$ alkoholat, sehingga asam humat membentuk kompleks dengan ion logam karena gugus ini dapat mengalami deprotonasi pada $\mathrm{pH}$ yang relatif tinggi.

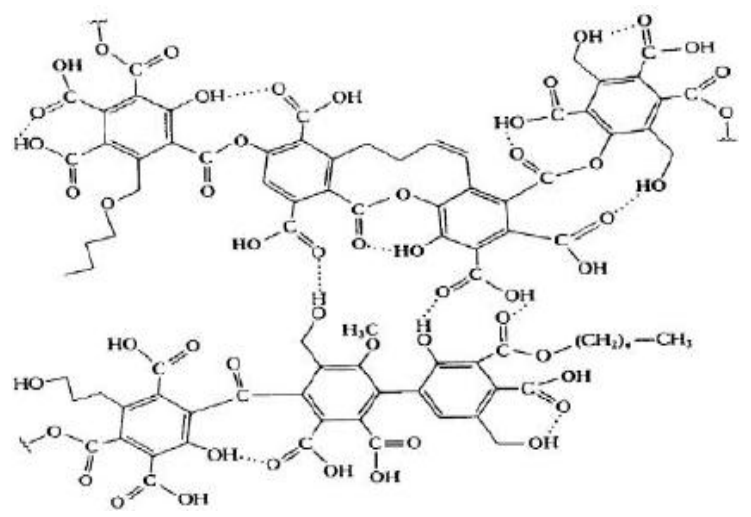

Gambar 1 Gugus Fungsional Asam Humat (Rahmawati, 2004).

Asam humat dalam meningkatkan kesuburan tanah dipengaruhi oleh: (1) atraksi elektrostatik atau tolakan muatan yang ada dalam molekul, (2) ikatan hidrogen sesama dan antar molekul. Secara umum, komposisi bahan organik tanah didominasi oleh fraksi humin yang berat molekulnya sangat besar, fraksi asam humat yang berat molekulnya sedang, dan fraksi asam fulfat yang berat molekulnya lebih rendah. Asam humat adalah fraksi yang larut dalam alkali tetapi tidak larut dalam asam atau air. Asam humat mampu berinteraksi dengan ion logam, oksida dan hidroksida mineral karena mengandung gugus fungsional aktif seperti karboksil, fenol, karbonil, hidroksida, alkohol, amino, kuinon dan metoksil, serta bentuknya yang berpori sehingga memiliki luas permukaan yang besar. Asam ini berpengaruh kuat terhadap kapasitas penjerapan tanah (Stevenson, 1994).

Kandungan asam-asam organik dari bahan kompos telah dipelajari oleh Rahmawati (2004) dengan melihat karakterisasi asam humat yang dihasilkan dari hasil ekstraksi kompos gambut dan kompos daun karet menunjukkan bahwa kualitas bahan sangat menentukan kandungan asam humat dan asam fulvat yang dihasilkan serta sifat kimia lainnya. Rahmawati (2004) juga menerangkan bahwa kemasaman total dari gugus karboksil $(\mathrm{COOH})$ dan gugus fenol $(-\mathrm{OH})$ meningkat $(7,84$ - 12,17) me/g setelah gambut dikomposkan, kemasaman total yang tinggi merefleksikan kompleksasi yang tinggi ataupun kapasitas khelat yang tinggi dari asam humat. Menurut Wahyudi, (2009) menunjukkan manfaat pemberian kompos pada tanah (Vertic Hapludult) yang diberikan tambahan (2\%) kompos dari jerami padi yang masih mentah $(\mathrm{C} / \mathrm{N}>45)$ akan meningkatkan kandungan asam humat pada bahan campuran sampai hampir 50 kali lipat lebih besar dari kandungan asam humat pada bahan kompos itu sendiri dan meningkatkan produksi tanamanan uji.

\section{KARAKTERISASI ASAM HUMAT}

Asam humat memiliki komposisi unsur $\mathrm{C}$ 40-80\%, N 2-4\%, S 1-2\%, dan P 0-0,3\%. Asam humat mengandung lebih banyak unsur $\mathrm{H}, \mathrm{C}$, $\mathrm{N}$ dan $\mathrm{S}$. Kadar unsur $\mathrm{O}$ asam humat lebih sedikit dibanding asam fulfat (Gaffney et al., 1996).

Asam humat memiliki kemampuan untuk mengikat ion logam maupun senyawa organik. Tan (2003) menyatakan bahwa muatan negatif pada gugus-gugus yang terkandung dalam asam humat memiliki kemampuan untuk bereaksi dan berinteraksi dengan ion-ion yang bermuatan positif. Ion logam seperti $\mathrm{Fe}$ yang memiliki muatan positif, sangat memungkinkan untuk dapat bereaksi dan berinteraksi dengan asam humat. Tan (2003) menyatakan pula bahwa reaksi dan interaksi asam humat dengan ion logam dapat terjadi melalui adsorpsi ikatan kompleks dan khelat.

Kemasaman total atau kapasitas tukar senyawa-senyawa humat dalam tanah disebabkan oleh adanya proton pada gugus 
karboksilat aromatik, alifatik, dan gugus $-\mathrm{OH}$ fenolat yang terdisosiasi atau ion-ion $\mathrm{H}^{+}$. Secara umum asam humat dicirikan oleh lebih rendahnya kemasaaman total dan kandungan gugus karboksilat 2-3 kali lebih rendah daripada asam fulvat (Rahmawati, 2004). Sejumlah metode yang digunakan untuk penetapan jumlah gugus karboksil dalam senyawa asam humat antara lain: metode pertukaran ion, dekarboksilasi, iodometri, esterifikasi dan prosedur Ca-asetat.

\section{EKSTRAKSI DAN FRAKSIONASI ASAM HUMAT}

Sejumlah metode tersedia untuk ekstraksi dan isolasi bahan humat dari tanah. Pemilihan pengekstrak yang cocok didasarkan pada dua pertimbangan, yaitu (1) Pengekstrak seharusnya tidak mempunyai pengaruh dalam merubah fisik dan kimia bahan yang diekstrak (2) Pengekstrak harus dapat secara kuantitatif memisahkan bahan humat dari tanah (Tan, 1993).

Pemisah asam humat didasarkan atas kelarutannya dalam asam dan alkali. Berdasarkan hal ini senyawa humat dapat dipisahkan dalam beberapa fraksi humat (Tabel 1).

Tabel 1 Pemisahan Senyawa Humat dalam Beberapa Fraksi Humat

\begin{tabular}{lccc}
\hline Fraksi & Alkali & Asam & Alkohol \\
\hline Asam Fulvat & Larut & Larut & - \\
Asam Humat & Larut & $\begin{array}{c}\text { Tidak } \\
\text { larut }\end{array}$ & Tidak \\
larut \\
Asam & & Tidak & Larut \\
Himatomelanik & Larut & larut & \\
Humin & Tidak & Tidak & Tidak \\
& larut & larut & larut \\
\hline
\end{tabular}

Sumber : Stevenson (1982)

Beberapa pelarut anorganik berupa basa dan garam yang telah dilaporkan antara lain: $0.1 \mathrm{~N} \mathrm{NaOH}, 0.5 \mathrm{~N} \mathrm{NaOH}, 0.1 \mathrm{M} \mathrm{Na}_{2} \mathrm{CO}_{3}, 0.1 \mathrm{M}$

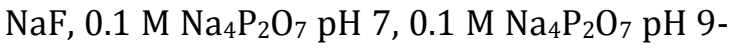
10. Di antara pengekstrak-pengekstrak tersebut, $\mathrm{NaOH}$ dan $\mathrm{Na}_{4} \mathrm{P}_{2} \mathrm{O}_{7}$ adalah yang paling banyak digunakan dalam ekstraksi. Senyawa $\mathrm{NaOH}$ diperkenalkan pertama kali pada tahun 1919 oleh Oden sebagai bahan pengekstrak dalam suatu metode analisi merupakan pengekstrak yang paling efektif dalam pemisahan bahan humat dalam tanah secara kuantitatif.

Pelarut organik yang digunakan untuk ekstraksi bahan-bahan humat adalah asam oksalat, asam format, fenol, benzena, kloroform, atau campuran dari pelarutpelarut tersebut, asetil aseton, heksametil entetramina, deoksisulfat, dan urea (Schnitzer, 1978).

\section{MANFAAT ASAM HUMAT DALAM MENJERAP TIMBAL}

Pertumbuhan industri dan kemajuan teknologi yang pesat telah membawa dampak terhadap lingkungan dengan dihasilkannya buangan hasil industri yang mengandung zatzat kimia yang berbahaya.

Di antara zat-zat kimia yang berbahaya tersebut adalah logam berat. Secara umum, hampir semua logam berpotensi sebagai pencemar lingkungan dan bersifat toksik bagi organisme jika konsentrasinya di lingkungan melampaui ambang batas tertentu.

Menurut Freedman (1995), logam berat seperti perak (Ag), kadmium (Cd), krom (Cr), timbal $(\mathrm{Pb})$, kobalt $(\mathrm{Co})$, tembaga $(\mathrm{Cu})$, besi (Fe), merkuri (Hg), molibdenum (Mo), nikel (Ni), timah (Sn), seng (Zn) dan unsur-unsur yang lebih ringan seperti alumunium (Al), arsen (As), dan selenium (Se) berpotensi besar mengakibat-kan efek toksik bagi organisme.

Salah satu dari karakteristik yang paling khas dari senyawa humat adalah kemampuannya untuk berinteraksi dengan ion logam, oksida, hidroksida, mineral dan organik, termasuk zat pencemar beracun lainnya. Sejumlah senyawa organik dalam tanah mampu mengikat ion-ion logam yang berlebih, sehingga jumlahnya menjadi lebih sedikit dalam larutan tanah sebagaimana 
dibutuhkan oleh tanaman. Disamping itu, khelat logam organik (organo-metal) yang terbentuk memiliki sifat yang tidak larut. Fenomena ini sangat penting dalam menjaga kualitas lingkungan, dengan mengurangi bahaya toksisitas logam berat terhadap tanaman, ternak dan manusia (Orlov, 1985).

Pembentukan kompleks metal-organik memegang peranan penting dalam mengontrol konsentrasi dan jumlah logamlogam berat dalam tanah. Pembentukan kompleks, kadar suatu logam berat dapat diturunkan hingga ke taraf non toksik (Stevenson, 1994). Hal ini sesuai dengan penelitian yang telah dilakukan oleh Wardani (2002), yang menyatakan bahwa perlakuan asam humatnya menurunkan kadar timbal $\mathrm{Pb}$ tersedia dalam tanah, sehingga mampu mengingkatkan bobot kering tanaman dan menurunkan serapan timbal oleh tanaman.

Kemampuan asam humat bereaksi dengan logam trace dilaporkan oleh Varrault dkk. (2000), dimana asam humat cocok sebagai agen pengikat logam trace dalam tanah. Hal ini dapat meminimalkan resiko masuknya logam trace ke air bawah tanah (groundwater) dan meminimalkan penyerapan kontaminan oleh tanaman.

Terdapat dua kemungkinan yang terjadi pada ikatan logam-asam humat dengan menimbulkan implikasi lingkungan yang berbeda terhadap mobilitas dan migrasi logam yaitu:

- Ion-ion logam membentuk kompleks logam-organik yang larut, dengan demikian menahan logam tersebut dalam larutan tanah

- Membentuk kompleks tak larut, menyebabkan berkurangnya ketersediaan hayati (bioavailability) akibat ekotoksisitas logam tersebut (Varrault dkk., 2000).

Gugus-gugus fenolat dan karboksilat pada asam humat dan asam fulvat diyakini sebagai sisi adsorpsi yang paling aktif, dengan demikian efisiensi adsorpsi logam berat pada asam humat sangat dipengaruhi oleh $\mathrm{pH}$.

\section{DAFTAR PUSTAKA}

Gaffney, J.S., Marley, N.A., and Clarck, S.B. 1996. Humic and Fulvic Acids : Isolation, Structure and Environmental Rol. American Chemical Society. Washington, DC.

Orlov, D. S. 1985. Humus Acid of Soils. Moscow University Publisher, Moscow.

Rahmawati, A. 2004. Studi Adsoprsi Kadnium(II) dan Timbal(II) pada Asam Humat. Universitas Gadjah Mada, Yogyakarta.

Schnitzer, M. and S. Khan. U. 1978. Soil Organic Matter. Elsevier Scientific Publishing Company, Amsterdam.

Stevenson. 1994. Humus Chemistry Genesis, Composition and Reaction. John Wiley and Sons, New York.

Tan. 1996. Dasar-Dasar Kimia Tanah terjemahan oleh Gunadi, D. H. dan Radjagukguk, B. Gajah Mada University Press, Yogyakarta.

Tan. 2003. Humic Matter in Soil and the Environment. CRC Press, New York.

Varrault, G., Camel, V., and Bermond, A., 2000, Adsorption of Trace Metal Ion onto Humic Acid, p. 587-588, in: Proceedings 10th International Meeting of the International-Humic Substances Society, IHSS 10, 24-28 July 2000-Touluse (France).

Wahyudi, I. 2009. Serapan Tanaman Jagung (Zea mays L.) Akibat Pemberian Pupuk Guano Dan Pupuk Hijau Lantoro Pada Tanah Ultisol Wanga. Fakultas Pertanian. Universitas Tadulako. Sulawesi Tenggara.

Wardani, N. 2002. Pengaruh Pemberian Asam Humat Sebagai Bahan Amelioran Tanah Terhadap Pertumbuhan dan Serapan Timbal Tanaman Bayam (Amaranthus sp.) pada Tanah yang Tercemar Logam Berat Timbal $(\mathrm{Pb})$. Skripsi. Institut Pertanian Bogor, Bogor. 
